\title{
Clostridium pfennigii sp. nov. Uses Methoxyl Groups of Monobenzenoids and Produces Butyrate
}

\author{
L. R. KRUMHOLZ ${ }^{1}$ AND M. P. BRYANT ${ }^{1,2 *}$ \\ Departments of Dairy Science ${ }^{1}$ and Microbiology, ${ }^{2}$ University of Illinois, Urbana, Illinois 61801
}

\begin{abstract}
The new bacterial species Clostridium pfennigii obtained energy for growth by catabolizing pyruvate to acetate and $\mathrm{CO}_{2} ; \mathrm{CO}$ to acetate and butyrate; vanillin to butyrate, protocatechuic aldehyde, and protocatechuate; ferulate to butyrate, caffeate, and hydrocaffeate; and syringate and 3,4,5-trimethoxybenzoate to butyrate and gallate. This new species did not use any other energy source, such as sugars, amino acids, other organic acids (including formate), methanol, ethanol, or $\mathrm{H}_{2}-\mathrm{CO}_{2} . C$. pfennigii is a small, motile, anaerobic, gram-positive, monotrichous rod-shaped organism with a lateral to subterminal flagellum, oval subterminal to terminal spores, and a deoxyribonucleic acid guanine-plus-cytosine content of $38 \mathrm{~mol} \%$. It did not liquefy gelatin. Based on the features described above, $C$. pfennigii may be closely related to Acetobacterium woodii. However, strain V5-2 ${ }^{\mathrm{T}}$ ( $\mathrm{T}=$ type strain) used pyruvate but did not use sugars or one-carbon compounds other than $\mathrm{CO}$; it produced acetate and butyrate. The stoichiometry of substrate utilization and the growth yields from different energy sources are discussed.
\end{abstract}

Methoxylated benzenoids are commonly found in the diets of ruminants and nonruminants as derivatives of cinnamic and benzoic acids ester linked to carbohydrates. Bacteria within mammalian gastrointestinal tracts modify benzenoid monomers by dehydroxylation (3), saturation of the propenoate side chains of cinnamate derivatives (4), decarboxylation of benzoic acid derivatives (9), and demethoxylation of methyl ether derivatives (8).

Acetobacterium woodii (2) was isolated from anaerobic digestor sludge and freshwater sediments after enrichment with vanillate (3-methoxy-4-hydroxybenzoate) and produced protocatechuate and acetate (1). This interesting fermentation by $A$. woodii also occurred with a number of other methoxylated compounds, including ferulate, syringate, sinapate, and anisole. Eubacterium limosum, which was isolated from sheep fed a liquid molasses-based diet, carries out a similar process (B. R. S. Genthner, Ph.D. thesis, University of Illinois, Urbana, 1984), but it is not found in rumina when mature animals are on more normal diets.

In recent studies our goal was to isolate and characterize the rumen bacteria which have the ability to cleave methyl ether linkages of benzenoids and which use the methoxyl groups as energy sources. "Syntrophococcus sucromutans" was the most numerous rumen species carrying out this process. It used carbohydrates as electron donors and electron acceptors, such as methoxyl groups of monobenzenoids, to produce acetate (Krumholz and Bryant, Arch. Microbiol., in press). Clostridium pfennigii, which is described in this paper, ferments methoxyl groups of monobenzenoids and produces the corresponding hydroxybenzenoids and butyrate.

\section{MATERIALS AND METHODS}

Anaerobic methods and media. The anaerobic methods and media used were similar to those described elsewhere (Krumholz and Bryant, in press). C. pfennigii strain V5-2 ${ }^{\mathrm{T}}$ ( $\mathrm{T}=$ type strain) was isolated after enrichment from $10 \mu \mathrm{l}$ of rumen fluid from a steer fed alfalfa hay $(70 \%)$ and grain $(30 \%)$. The enrichment medium contained $5 \mathrm{mM}$ vanillate, $5 \%$ $(\mathrm{vol} / \mathrm{vol})$ rumen fluid, mixtures of $\mathrm{B}$ vitamins and minerals, 1

\footnotetext{
* Corresponding author.
}

$\mathrm{mM} \mathrm{Na} 2 \mathrm{~S}, 40 \mathrm{mM} \mathrm{NaHCO} 3$, and an $1 \mathrm{~N}_{2}-\mathrm{CO}_{2}(4: 1)$ gas phase; the $\mathrm{pH}$ of this medium was 7.2. The reducing solution was changed, after a few transfers of the culture, to $1 \mathrm{mM} \mathrm{Na}_{2} \mathrm{~S}-2$ $\mathrm{mM}$ cysteine. Strain V5-2 $2^{\mathrm{T}}$ was isolated from roll tubes containing the enrichment medium supplemented with $2 \%$ Bacto-agar (Difco Laboratories, Detroit, Mich.); manipulations were carried out as described by Genthner et al. (5). After isolation, strain V $5-2^{\mathrm{T}}$ was grown in basal medium supplemented with an energy source, as well as $30 \%$ rumen fluid and $0.2 \%$ yeast extract. Preparations were incubated at $39^{\circ} \mathrm{C}$.

The analytical methods used have been described elsewhere (Krumholz and Bryant, in press).

\section{RESULTS AND DISCUSSION}

Demethoxylation of monobenzenoid acids has been shown to occur in sheep when vanillate is infused into the rumen, and the products are recovered in the urine. The resultant hydroxybenzenoids are predominantly catechol (2-hydroxyphenol) and a small amount of guaiacol (2methoxyphenol) (8). Identical products along with protocatechuate were observed when vanillate was incubated anaerobically with rat cecal contents (9). In similar studies (10), vanillin was catabolized via the following two

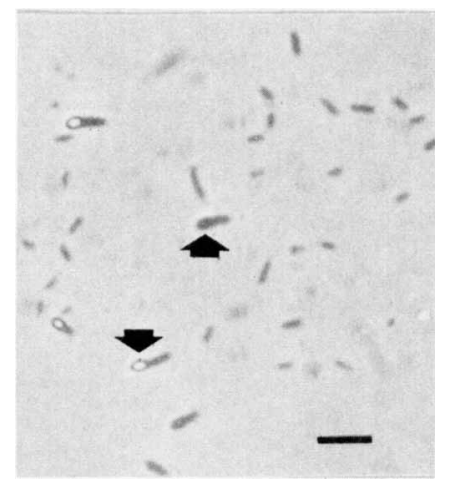

FIG. 1. Phase-contrast micrograph of strain V5-2 ${ }^{\mathrm{T}}$. The arrows indicate spores. Bar $=5 \mu \mathrm{m}$. 
TABLE 1. Fermentation products other than benzenoids, final optical densities, and generation times for strain $\mathrm{V} 5-2^{\mathrm{T}}$ obtained with various energy sources ${ }^{a}$

\begin{tabular}{|c|c|c|c|c|c|}
\hline \multirow{2}{*}{ Substrate } & \multirow{2}{*}{$\begin{array}{c}\text { Concn } \\
\text { (mM or } \\
\mathrm{mmol} / \text { liter) }\end{array}$} & \multicolumn{2}{|c|}{$\begin{array}{c}\text { Conen of } \\
\text { products }(\mathrm{mM})\end{array}$} & \multirow{2}{*}{$\begin{array}{c}\text { Final } \\
\text { optical } \\
\text { density }\end{array}$} & \multirow{2}{*}{$\begin{array}{l}\text { Generation } \\
\text { time (h) }\end{array}$} \\
\hline & & Acetate & Butyrate & & \\
\hline None & & 0.29 & 0 & 0 & \\
\hline \multirow[t]{2}{*}{ Vanillate } & 3 & 0 & 0.50 & 0.10 & 7.0 \\
\hline & 6 & 0 & 0.99 & 0.20 & 8.6 \\
\hline \multirow[t]{2}{*}{ Vanillin } & 3 & 0 & 0.54 & 0.12 & 6.6 \\
\hline & 6 & 0 & 1.16 & 0.19 & 11.4 \\
\hline \multirow[t]{2}{*}{ Ferulate } & 3 & 0 & 0.27 & 0.15 & $\mathrm{ND}^{b}$ \\
\hline & 6 & 0 & 0.68 & 0.26 & 10.8 \\
\hline \multirow[t]{2}{*}{ Syringate } & 1.5 & 0 & 0.51 & 0.12 & 8.9 \\
\hline & 3 & 0 & 0.96 & 0.21 & 9.0 \\
\hline \multirow[t]{2}{*}{ Trimethoxybenzoate } & 1.5 & 0 & 0.93 & 0.17 & 14.4 \\
\hline & 3 & 0 & 1.52 & 0.32 & 11.7 \\
\hline Pyruvate & ND & 5.33 & 0 & 0.35 & 7.3 \\
\hline \multirow[t]{2}{*}{$\mathrm{CO}$} & 12.4 & 2.00 & 0.08 & 0.11 & 34.2 \\
\hline & 25.3 & 2.61 & 0.43 & 0.21 & 13.9 \\
\hline
\end{tabular}

${ }^{a}$ All substrates except $\mathrm{CO}$ and pyruvate were used at limiting concentrations. The energy sources not used by strain V $5-2^{\mathrm{T}}$ were $5 \mathrm{mM}$ cellobiose, 5 $\mathrm{mM}$ maltose, $5 \mathrm{mM}$ anisole, $5 \mathrm{mM}$ p-methoxybenzoate, $5 \mathrm{mM}$ protocatechuate, $5 \mathrm{mM}$ methanol, $10 \mathrm{mM}$ glucose, $10 \mathrm{mM}$ mannitol, $10 \mathrm{mM}$ citrate, $10 \mathrm{~m}$ ribose, $10 \mathrm{mM}$ fructose, $20 \mathrm{mM}$ fumarate, $20 \mathrm{mM}$ succinate, $20 \mathrm{mM}$ malate, 20 $\mathrm{mM}$ aspartate, $20 \mathrm{mM}$ glutamate, $20 \mathrm{mM}$ glycine, $20 \mathrm{mM}$ 3-hydroxybutyrate, $20 \mathrm{mM}$ valine, $20 \mathrm{mM}$ serine, $20 \mathrm{mM}$ isoleucine, $20 \mathrm{mM}$ acrylate, $20 \mathrm{mM}$ butyrate, $50 \mathrm{mM}$ ethanol, $50 \mathrm{mM}$ lactate, $50 \mathrm{mM}$ formate, and $\mathrm{H}_{2}-\mathrm{CO}_{2}$ (4:1; $202 \mathrm{kPa}$ ). The data are the mean results from three serum tubes (18 by 150 $\mathrm{mm}$ ) containing $10 \mathrm{ml}$ of medium $(16 \mathrm{ml}$ of gas phase). Concentrations of substrates other than $\mathrm{CO}$ are millimolar; $\mathrm{CO}$ concentrations are in millimoles per liter of medium.

${ }^{b}$ ND, Not determined.

pathways: oxidation to vanillate and via a reductive route to 4-methylcatechol and 4-methylguaiacol. "S. sucromutans" and strain $V 5-2^{\mathrm{T}}$, which were isolated from bovine rumina, used the former pathway.

Strain $\mathrm{V} 5-2^{\mathrm{T}}$ had many metabolic similarities to $A$. woodii, to which it may be phylogenetically related. However, unlike $A$. woodii, it produced heat-resistant spores. Although $16 \mathrm{~S}$ ribosomal ribonucleic acid data often indicate that spore formation does not correlate with phylogeny, in accordance with current taxonomic systems we place strain V $5-2^{\mathrm{T}}$ in the genus Clostridium, as described below.

Clostridium pfennigii sp. nov. Clostridium pfennigii (pfen.nig'i.i L. gen. n. pfennigii named after Norbert Pfennig, who first documented the catabolism of methoxyl groups of benzenoid compounds by an anaerobic bacterium) surface colonies are 2 to $3 \mathrm{~mm}$ in diameter, smooth, convex, entire, and opaque after 1 week of incubation in roll tube medium supplemented with $5 \mathrm{mM}$ vanillate. In liquid medium cultures are evenly turbid.

Strain V5-2 ${ }^{\mathrm{T}}$ cells are gram positive, motile, slightly curved, rod shaped, and about $0.4 \mu \mathrm{m}$ wide by 1.6 to $3.5 \mu \mathrm{m}$ long and have rounded to slightly tapered ends. The cells usually occur singly and in division stages (Fig. 1). Electron microscopy reveals a single laterally to subterminally attached flagellum. Spores are resistant to boiling for $3 \mathrm{~min}$; they are oval, subterminal to terminal, and $0.4 \mu \mathrm{m}$ wide by 0.4 to $0.8 \mu \mathrm{m}$ long and slightly swell the sporangium.

Strain V5-2 ${ }^{\mathrm{T}}$ grows only with methoxybenzenoids, pyruvate, or $\mathrm{CO}$ added to the medium (Table 1). Butyrate and hydroxybenzenoids are the only organic products of methoxybenzenoids. $\mathrm{CO}$ is catabolized to acetate and butyrate. Pyruvate is fermented to acetate. The methoxybenzenoids are catabolized to hydroxybenzenoids as follows: vanillate (3-methoxy-4-hydroxybenzoate) to protocatechuate (3,4-dihydroxybenzoate); vanillin (3methoxy-4-hydroxybenzaldehyde) to protocatechuic aldehyde and protocatechuate; ferulate [3-(3-methoxy-4hydroxyphenyl)-2-propenoate] to caffeate [3-(3,4dihydroxyphenyl)-2-propenoate] and hydrocaffeate [3(3,4-dihydroxyphenyl)-propionate]; and syringate $(3,5$-dimethoxy-4-hydroxybenzoate) and 3,4,5-trimethoxybenzoate to gallate (3,4,5-trihydroxybenzoate). No other substrates are utilized (Table 1). $\mathrm{CO}_{2}$ is produced from $\mathrm{CO}$ and pyruvate, but is not significantly produced during growth on benzenoids. $\mathrm{No} \mathrm{H}_{2}$, other organic acids, ethanol, or methanol production have been observed.

The equations that best fit the results shown in Table 1 are as follows:

$$
\begin{gathered}
\text { Vanillate }^{-}+0.2 \mathrm{HCO}_{3}^{-} \leftrightharpoons \text { Protocatechuate }^{-}+ \\
0.3 \text { Butyrate }^{-}+0.1 \mathrm{H}^{+}
\end{gathered}
$$

Vanillin $+0.3 \mathrm{HCO}_{3}{ }^{-} \leftrightharpoons 0.75$ Protocatechuic aldehyde + 0.25 Protocatechuate ${ }^{-}+0.325$ Butyrate $^{-}+0.275 \mathrm{H}^{+}$

Ferulate $^{-}+0.5 \mathrm{H}_{2} \mathrm{O} \leftrightharpoons 0.5$ Caffeate $^{-}+0.5$ Hydrocaffeate $^{-}+0.25$ Butyrate $^{-}+0.25 \mathrm{H}^{+}$

$$
\begin{gathered}
\text { Syringate }^{-}+0.4 \mathrm{HCO}_{3}^{-} \leftrightharpoons \text { Gallate }^{-}+0.6 \text { Butyrate }^{-} \\
+0.2 \mathrm{H}^{+}
\end{gathered}
$$

Trimethoxybenzoate ${ }^{-}+0.6 \mathrm{HCO}_{3}^{-} \leftrightharpoons$ Gallate $^{-}$ +0.9 Butyrate $^{-}+0.3 \mathrm{H}^{+}$

Maximum optical density is linear with vanillate concentrations up to at least $10 \mathrm{mM}$. Cell protein yield is $8.17 \pm 0.53$ $\mathrm{g} / \mathrm{mol}$ of ferulate (mean \pm standard error of three cultures

\begin{tabular}{|c|c|c|c|c|c|}
\hline \multirow[b]{2}{*}{ Substrate } & \multicolumn{5}{|c|}{$\mathrm{g}(\mathrm{dry} \mathrm{wt}) / \mathrm{mol}$ of substrate ${ }^{u}$} \\
\hline & C. pfennigii & A. woodii & $\begin{array}{l}\text { "Butyribacterium } \\
\text { methylotrophicum" }\end{array}$ & E. limosum & $\begin{array}{l}\text { Peptostrepto- } \\
\text { coccus productus }\end{array}$ \\
\hline Vanillate & 9.72 & $7.30(1)$ & & & \\
\hline Vanillin & 10.50 & & & & \\
\hline Ferulate & 13.62 & $10.30(1)$ & & & \\
\hline Syringate & 10.94 & $6.36(1)$ & & & \\
\hline Trimethoxybenzoate & 10.37 & $6.64(1)$ & & & \\
\hline $\mathrm{CO}$ & 2.50 & & $3.00(7)$ & $3.40^{b}$ & $2.2(6)$ \\
\hline
\end{tabular}
containing $3 \mathrm{mM}$ ferulate and three cultures containing $6 \mathrm{mM}$ ferulate). The growth yields of a number of acetogens,

TABLE 2. Cell yields

"Yields for $C$. pfennigii and $P$. productus were calculated on the assumption that cells were $60 \%$ protein. Actual cell protein was measured for $C$. pfennigii strain V $5-2^{\mathrm{T}}$ growing on ferulate. With substrates other than ferulate, growth (optical density) of $C$. pfennigii was assumed to be proportional to cell protein. The means for two levels of each energy source with triplicate tubes are shown for strain V5-2 ${ }^{\mathrm{T}}$. Literature citations are in parentheses.

${ }^{b}$ Data from B. R. S. Genthner (Ph.D. thesis). 
including $C$. pfennigii, are compared in Table 2 . There was a significant improvement in cell yields when the organisms were grown on ferulate, probably due to the reduction of the acrylate side chains (11).

Little is known about nutritional requirements, but growth is best with $30 \%$ rumen fluid $(0,5,10,20$, and $30 \%$ tested), $0.2 \%$ yeast extract, and a specific energy source(s) in medium containing bicarbonate, minerals, cysteine, sulfide, and a mixture of water-soluble vitamins. Very little growth occurs without rumen fluid (optical density, 0.03). The addition of Casitone, Casamino Acids, 1,4-naphthoquinone, hemin, or a mixture of volatile fatty acids to media with or without rumen fluid does not stimulate growth. No growth occurs without an added energy source. Neither sulfate, thiosulfate, nitrate, nor fumarate stimulates growth on syringate, and nitrate is not reduced during growth in this medium. The addition of sulfate does not allow growth on lactate or ethanol. Gelatin is not liquefied.

The $\mathrm{pH}$ range for growth is 6.3 to at least 8.0 ; the optimum $\mathrm{pH}$ is 7.3 .

The temperature range for growth is 23 to $39^{\circ} \mathrm{C}$; the optimum temperature is 36 to $38^{\circ} \mathrm{C}$.

The deoxyribonucleic acid base ratio is $38 \mathrm{~mol} \%$ guanine plus cytosine (thermal denaturation method). Habitat: isolated from rumina of cattle.

The type strain is strain V5-2 (= DSM 3222).

\section{ACKNOWLEDGMENTS}

We thank the Center for Electron Microscopy of the University of Illinois, Urbana-Champaign, for the use of their facilities and I.C. Gunsalus for the use of the model DU-8 spectrophotometer used for thermal denaturation measurements.

This research was supported by contract DE-AC02-81ER10874 from the U.S. Department of Energy and by the Agricultural Experiment Station, University of Illinois. L.R.K. received support from the Natural Sciences and Engineering Research Council of Canada.

\section{LITERATURE CITED}

1. Bache, R., and N. Pfennig. 1981. Selective isolation of Acetobacterium woodii on methoxylated aromatic acids and determination of growth yields. Arch. Microbiol. 130:255-261.

2. Balch, W. E., S. Schoberth, R. S. Tanner, and R. S. Wolfe. 1977. Acetobacterium, a new genus of hydrogen-oxidizing, carbon dioxide-reducing, anaerobic bacteria. Int. J. Syst. Bacteriol. 27:355-361.

3. Booth, A. N., and R. T. Williams. 1963. Dehydroxylation of catechol acids by intestinal contents. Biochem. J. 88:66.

4. Chesson, A., C. S. Stewart, and R. J. Wallace. 1982. Influence of plant phenolic acids on growth and cellulolytic activity of rumen bacteria. Appl. Environ. Microbiol. 44:597-603.

5. Genthner, B. R. S., C. L. Davis, and M. P. Bryant. 1981. Features of rumen and sewage sludge strains of Eubacterium limosum, a methanol- and $\mathrm{H}_{2}-\mathrm{CO}_{2}$-utilizing species. Appl. Environ. Microbiol. 42:12-19.

6. Lorowitz, W. H., and M. P. Bryant. 1984. Peptostreptococcus productus strain that grows rapidly with $\mathrm{CO}$ as the energy source. Appl. Environ. Microbiol. 47:961-964.

7. Lynd, L., R. Kerby, and J. G. Zeikus. 1982. Carbon monoxide metabolism of the methylotrophic acidogen Butyribacterium methylotrophicum. J. Bacteriol. 149:255-263.

8. Martin, A. K. 1982 . The origin of urinary aromatic compounds excreted by ruminants. III. The metabolism of phenolic compounds to simple phenols. Br. J. Nutr. 48:497-507.

9. Scheline, R. R. 1966. Decarboxylation and demethylation of some phenolic benzoic acid derivatives by rat cecal contents. J. Pharm. Pharmacol. 18:664-669.

10. Scheline, R. R. 1978. Mammalian metabolism of plant xenobiotics. Academic Press, Inc., London.

11. Tschech, A., and N. Pfennig. 1984. Growth yield increase linked to caffeate reduction in Acetobacterium woodii. Arch. Microbiol. 137:163-167. 